\title{
Using Selected Data-Mining Methods in the Analysis of Data Concerning the Attitudes of Students towards the Issue of Vaccination
}

\author{
Marcin Milewski ${ }^{1}$, Karolina Milewska ${ }^{1}$, Anna Justyna Milewska ${ }^{2}$ \\ 1 Scientific Group at Department of Statistics and Medical Informatics, Medical Univer- \\ sity of Bialystok, Poland \\ 2 Department of Statistics and Medical Informatics, Medical University of Bialystok, \\ Poland
}

\begin{abstract}
Preventive vaccination is one of the greatest successes of modern medicine. The SARS-CoV-2 epidemic, during which vaccination is the main method of prevention against death and severe disease, gave rise to a resurgence of anti-vaccine (anti-vax) movements. The aim of this study was to analyse the attitudes of students towards vaccination and the COVID-19 pandemic. The statistical analysis was performed with the use of the following data-mining methods: correspondence analysis and basket analysis. The obtained results show that students of medicine are characterized with the highest level of knowledge. Students of other medical faculties, on the other hand, have a significantly less uniform views, as do students of non-medical faculties.
\end{abstract}

\section{Introduction}

As early as from June 6, 1885 - when 9-year-old Joseph Master, after having been bitten by an infected dog, was administered the rabies vaccine invented by Louis Pasteur, which protected him against premature death - mankind has been accompanied by vaccines (Cohn, 2006; Wood, 2016). Admittedly, several hundred years earlier, on the territory of present-day China, a similar procedure had been performed, one which may be regarded as a prototype of vaccination, i.e. variolation. It consisted in preventive infection of healthy persons, mainly children, with smallpox, by inserting a swab saturated with an aqueous extract from the scabs of a person who had had an exceptionally mild case of smallpox into the nostril of a patient for a few hours. In his 1579 work, Weng Zhongren states that inexperienced or dishonest medics, due to a lack of knowledge or on purpose, for easy profit, used scabs from seriously ill patients for the pro- 
cedure of variolation, which resulted in a high mortality rate of up to $15 \%$, among those who underwent the procedure (Needham, 2004). In 1896, Wilhelm Kolle designed the first dead vaccine, i.e. the cholera vaccine, which was characterized by the impossibility of causing the disease in the vaccinated person as it did not contain live bacteria that would cause the disease (Artenstein, 2009).

Owing to the invention of vaccination, it has been possible for huge numbers of people to avoid falling ill with diseases that in their severe form often result in the death of the infected person. From the very beginning, vaccines, similarly to all innovations, have been accompanied by people voicing their fear of the unknown. They often take a more radical form, attributing many more unconfirmed adverse effects to the innovation than it actually has. Such was, and still is, the case with vaccines. Although the range of negative health effects that, according to some people, are caused by vaccines may seem less far removed from reality than the $19^{\text {th }}$ century theory of people turning into cattle after having been vaccinated with the cowpox virus (Williams, 2010), today's theories are also very creative, e.g. those that posit that the vaccines contain microscopic devices capable of remotely controlling human behaviour.

However, not every vaccine sceptic believes in absurd theories; some of them believe in those that did use to be probable at some point but have since been disproven. Some misquote scientific articles in a language that they do not know, ones that not only do not prove, but often disprove the propagated assertions. Nevertheless, the very act of providing the source is often enough to convince another person, who also will not read the article. Some other people are guided by emotions and instinct, based on the assumption that because so many people say something is true, then it must be so. It can be seen that the scope of the phenomenon of hostile attitudes towards vaccination has been especially exacerbated during the current pandemic-related situation. The better educated an individual is, the less commonly they believe in anti-vax theories. Nowadays, however, regardless of their level of education, most people have access to the Internet, which results in the huge popularity of anti-vax content. The large number of proponents of those theories and the undecided persons, who on the one hand do not fully believe in them and do not fully trust the information given by public media on the other while also lacking knowledge concerning the vaccines, results in real and tangible deterioration of the epidemic situation. This translates into destabilization, which depending on the point of view may be beneficial for some people, but certainly not for the life and health of citizens, especially the elderly and immunosuppressed persons, in whose 
case premature death is the direct result of the increasing popularity of antivax content (Marchewka et al., 2015; Owczarek, 2021).

It is extremely difficult to convince those who believe in anti-vax theories, similarly to the case with other conspiracy theories, that their views are wrong. This is due to the fact that they often have a preconceived response to anything that contradicts their beliefs. Therefore, the group that may change their mind would mostly consist of undecided persons; the question is, however, which social groups are dominated by undecided persons, which include persons who deny the effectiveness of vaccines, and which include people who believe in vaccines. Do these groups include people with medical education, or those who have just reached majority, or those in their fourth or later decade of life? Each of these social groups includes hesitant persons; people who deny the effectiveness of vaccines can be found both among those with primary education and among professors, even medical ones. It is possible to make assumptions about the ratios between groups with different attitudes towards vaccination, or the currently dominant subject matter of the COVID-19 pandemic. On the basis of these assumptions alone, however, it would be impossible to draw reliable conclusions, which is precisely the difference between science and pseudoscientific theories that people so commonly believe in (Marchewka et al., 2015; Owczarek, 2021). This is the reason why the study presented in this paper has been performed.

The aim of the paper was to find relations in the data concerning the topic of the attitudes towards vaccination among students of Polish universities with the use of selected data-mining methods.

\section{Material and Methods}

351 online surveys were analysed, which pertained to students' attitudes towards the topic of vaccination, with a particular focus on the SARSCoV-2 vaccines and the attitude towards the COVID-19 pandemic. Answers given in the survey were analysed divided by the type of faculty: medicine $(\mathrm{n}=56,16 \%)$, other medical $(\mathrm{n}=159,46 \%)$, non-medical $(\mathrm{n}=134,38 \%)$.

Correspondence analysis, basket analysis, and the chi-square test of independence were used in the statistical analysis to present co-occurrences of characteristics. Statistica 13.3 (TIBCO Software INC) software was used for the calculations. The results were considered statistically significant at $p<0.05$.

Correspondence analysis is a method that makes it possible to present large contingency tables graphically. Graphic presentation of the results of 
analyses in the form of a correspondence map consists in the assessment of the position of points illustrating the categories of variables on a graph, usually two-dimensional. Points that correspond to the levels of various characteristics that are located close to one another indicate the existence of correspondences between categories. On the other hand, when points are located at the opposite sides of the projection, this suggests a lack of correspondence (Stanimir, 2005).

Basket analysis is used to look for association rules, i.e. implication of the 'if $\mathrm{X}$ then probably $\mathrm{Y}$ ' type. Both the predecessor and the successor of the implication may contain several factors, making it possible to present complex relations, which are not easy to find with the traditional statistical methods (Tadeusiewicz, 2006).

Data-mining methods, including correspondence analysis and basket analysis, are increasingly often used in medical research. They allow to search large databases for hidden relations (Askell-Williams \& Lawson, 2004; Hristovski et al., 2001; Milewska et al., 2011; Milewska et al., 2012).

\section{Results and Discussions}

With the use of correspondence analysis, three questions from the conducted survey were presented, which pertained to vaccination and protective masks.

The first analysed question was: Have you been vaccinated against COVID-19? The answers and their frequency were as follows:

- Yes, with all the required doses $(\mathrm{n}=274,78 \%)$

- Yes, but not with all the required doses and I am waiting for the next one $(\mathrm{n}=4,1 \%)$

- Yes, but not with all the required doses and I do not intend to take another dose $(\mathrm{n}=2,1 \%)$

- No, but I intend to get vaccinated $(\mathrm{n}=21,6 \%)$

- No and I do not intend to get vaccinated $(\mathrm{n}=50,14 \%)$

Figure 1 shows the correspondence between faculty and COVID-19 vaccination. The first coordinate (inertia $66 \%$ ) separates medical faculties from non-medical ones. This means that answers to the questions differ between the two types of faculties. On the right side of the vertical axis there are the negative answers; on the left side - the positive answers. The other coordinate separates "Other medical" faculties from "Medicine". The most pronounced correspondence is: faculty of "Medicine" with the answer "Yes, with all the required doses". 
Using Selected Data-Mining Methods in the Analysis of Data Concerning...



Figure 1. Correspondence map: faculty vs. answer to the question: Have you been vaccinated against COVID-19?

On the basis of the division observed with the use of the first coordinate, a bivariate table was created (Table 1) and the chi-square test was performed, which confirmed the existence of a relation between the type of study (medical vs. non-medical), and the attitude towards vaccination $(p=0.0169)$.

Table 1. Correspondence between faculty and COVID-19 vaccination

\begin{tabular}{|l|l|l|c|}
\hline & $\begin{array}{l}\text { "No and I do not intend to } \\
\text { get vaccinated" } \\
\text { "Yes, but not with all the } \\
\text { required doses and I do not } \\
\text { intend to take another dose" } \\
\text { "No, but I intend to get } \\
\text { vaccinated" }\end{array}$ & $\begin{array}{l}\text { "Yes, with all the required } \\
\text { doses" } \\
\text { "Yes, but not with all the } \\
\text { required doses and I am } \\
\text { waiting for the next one" }\end{array}$ & Total \\
\hline $\begin{array}{l}\text { Medicine } \\
\text { Other medical }\end{array}$ & $35(16.3 \%)$ & $180(83.7 \%)$ & 215 \\
\hline Non-medical & $36(26.9 \%)$ & $98(73.1 \%)$ & 134 \\
\hline
\end{tabular}


The second analysed question was: Should wearing masks be compulsory? The answers and their frequency were as follows:

- Yes, and I think that the law should be more restrictive $(\mathrm{n}=81,23 \%)$

- Yes, and I think that the law should stay as it is now $(\mathrm{n}=156,44 \%)$

- Yes, but I think that the law should be less restrictive $(\mathrm{n}=51,15 \%)$

- No $(\mathrm{n}=63,18 \%)$

Figure 2 shows the correspondence between faculty and attitude towards wearing protective masks. The first coordinate (inertia 70\%) separates the faculty of medicine from the other ones. On the right side of the vertical axis, together with the faculty of medicine, there are the answers that indicate the need to strengthen the law and an acceptance of the current law. On the left side, together with the other faculties, there are the negative opinions. The other coordinate separates medical faculties from non-medical ones. The most pronounced correspondence is: the faculty of "Medicine" with the answer "the law should be more restrictive"; "Other medical" faculty with the answer "the law should be less restrictive"; and "Non-medical" faculty with the answer "masks should not be compulsory".

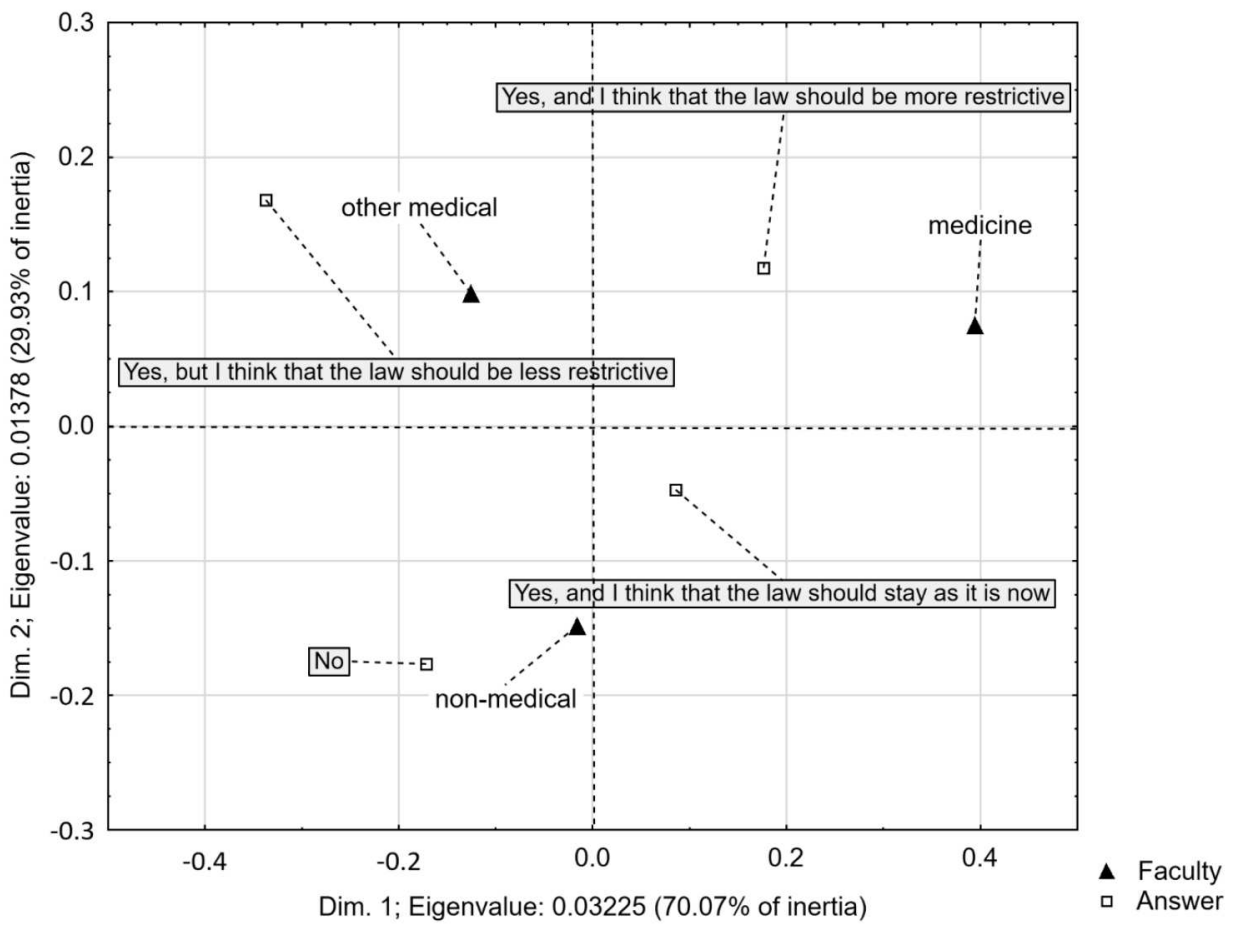

Figure 2. Correspondence map: faculty vs. answer to the question: Should wearing masks be compulsory? 
On the basis of the division observed with the use of the first coordinate, a bivariate table was created (Table 2) and the chi-square test was performed, which confirmed the existence of a relation between the type of study (medicine vs. other), and the attitude towards masks $(p=0.0018)$.

Table 2. Correspondence between faculty and opinion concerning mask-wearing

\begin{tabular}{|l|l|l|c|}
\hline & $\begin{array}{l}\text { "Yes, but I think that } \\
\text { the law should be less } \\
\text { restrictive" } \\
\text { "No" }\end{array}$ & $\begin{array}{l}\text { "Yes and I think that } \\
\text { the law should be more } \\
\text { restrictive" } \\
\text { "Yes and I think that the } \\
\text { law should stay as it is now" }\end{array}$ & Total \\
\hline Medicine & $8(14.3 \%)$ & $48(85.7 \%)$ & 56 \\
\hline $\begin{array}{l}\text { Other medical } \\
\text { Non-medical }\end{array}$ & $104(35.5 \%)$ & $189(64.5 \%)$ & 293 \\
\hline
\end{tabular}

The third analysed question was: Were the vaccines tested? The answers and their frequency were as follows:

- Yes, like all the available medicines, or even more thoroughly $(\mathrm{n}=196$, $56 \%)$

- Yes, but less thoroughly than the medicines available on the market $(\mathrm{n}=141,40 \%)$

- No, they were not tested $(\mathrm{n}=14,4 \%)$

Figure 3 shows the correspondence between faculty and knowledge about vaccines. The first coordinate (inertia 100\%) separates medical faculties from non-medical ones. This means that answers to the questions differ between the two types of faculties. On the right side of the vertical axis there is the answer "Yes, like all the available medicines, or even more thoroughly", together with medical faculties; on the right side, there are the negative answers ("No, they were not tested", "Yes, but less thoroughly") and non-medical faculties.

The chi-square test performed for the division according to the first coordinate showed that there exists a statistically significant relation $(p=0.0401)$ between faculty and knowledge about COVID-19 vaccines (Table 3). 
Marcin Milewski, Karolina Milewska, Anna Justyna Milewska

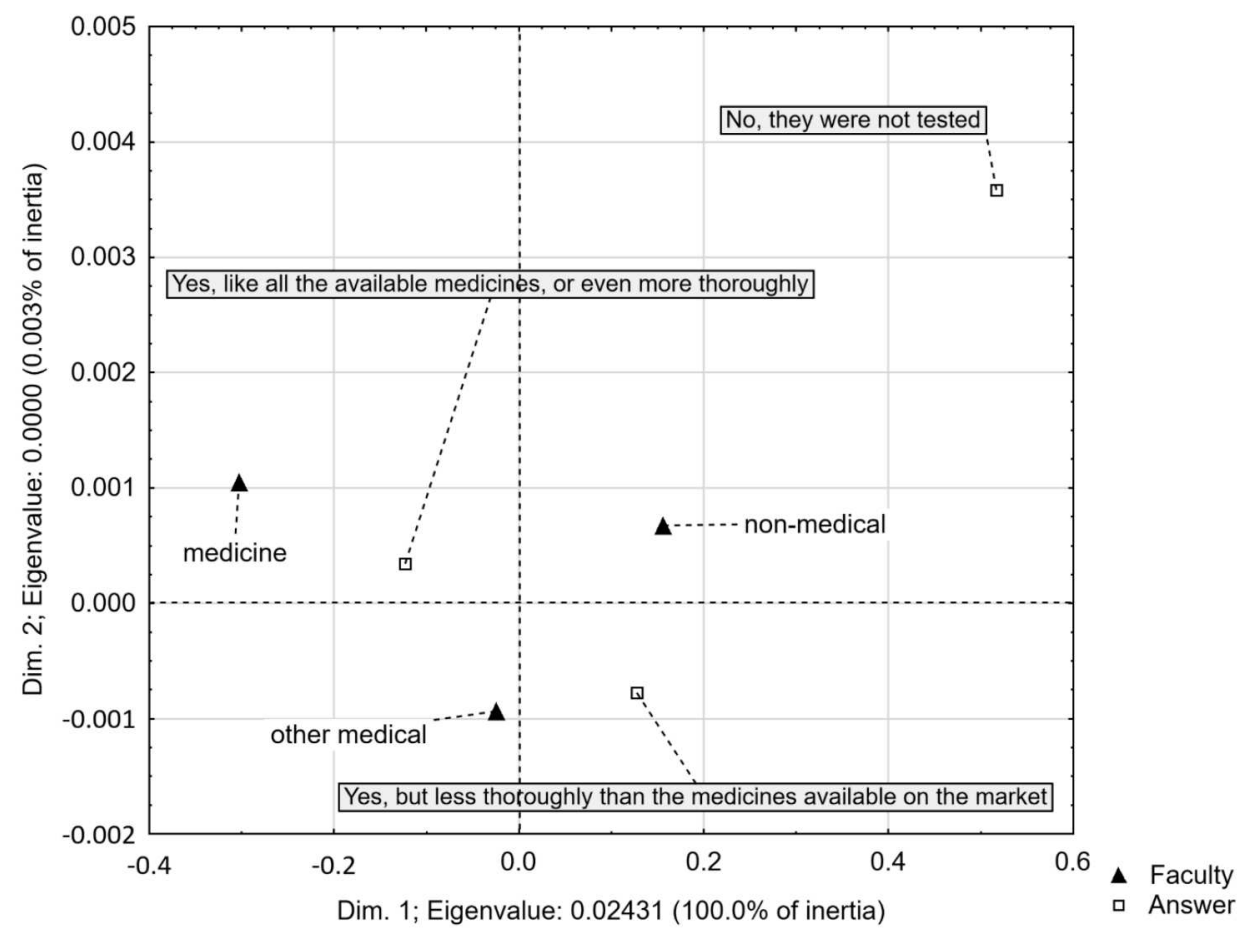

Figure 3. Correspondence map: faculty vs. answer to the question: Were the vaccines tested?

Table 3. Correspondence between faculty and opinion concerning studies on vaccines

\begin{tabular}{|l|l|l|c|}
\hline & $\begin{array}{l}\text { "Yes, but less thoroughly } \\
\text { than the medicines available } \\
\text { on the market" } \\
\text { "No, they were not tested" }\end{array}$ & $\begin{array}{l}\text { "Yes, like all the available } \\
\text { medicines, or even more } \\
\text { thoroughly" }\end{array}$ & Total \\
\hline $\begin{array}{l}\text { Medicine } \\
\text { Other medical }\end{array}$ & $85(39.5 \%)$ & $130(60.5 \%)$ & 215 \\
\hline Non-medical & $68(50.7 \%)$ & $66(49.3 \%)$ & 134 \\
\hline
\end{tabular}

The selected association rules, created as a result of the performed basket analysis, pertain to the faculty of the surveyed persons, examined by two groups: the faculty of medicine vs. other faculties.

- It was determined that over $91 \%$ of those surveyed who study at the faculty of medicine have been vaccinated against COVID-19 with all the required doses: 
Using Selected Data-Mining Methods in the Analysis of Data Concerning...

faculty $=$ medicine $\Rightarrow$ vaccinated against COVID-19 $=$ yes (support $14.53 \%$, trust $91.07 \%$ )

- Among the students of the faculty of medicine who have been vaccinated against COVID-19 with all the required doses, all believe in the existence of the SARS-CoV-2 virus (approx. $3.5 \%$ of all those surveyed did not believe in the existence of the virus):

faculty $=$ medicine $\&$ vaccinated against COVID-19 $=$ yes $\Rightarrow$ do you believe in the existence of SARS-CoV-2? = yes (support $14.53 \%$, trust $100 \%$ )

- Among the students of the faculty of medicine who have been vaccinated against COVID-19 with all the required doses, over $98 \%$ believe that hand washing and disinfection are efficient tools in the fight against the COVID-19 pandemic (approx. 9.5\% of all those surveyed had the opposite opinion):

faculty $=$ medicine $\&$ vaccinated against COVID-19 $=$ yes $\Rightarrow$ are hand washing and disinfection efficient tools in the fight against the COVID-19 pandemic $=$ yes (support $14.25 \%$, trust $98.04 \%$ )

- Among the students of the faculty of medicine who have been vaccinated against COVID-19 with all the required doses, over $94 \%$ believe that mask-wearing is an efficient tool in the fight against the COVID19 pandemic (over $31.5 \%$ of all those surveyed had the opposite opinion):

faculty $=$ medicine $\&$ vaccinated against COVID-19 $=$ yes $\Rightarrow$ is mask-wearing an efficient tool in the fight against the COVID-19 pandemic $=$ yes

(support $13.68 \%$, trust $94.12 \%$ )

- Among the students of up to and including the $3^{\text {rd }}$ year 3 who believed that mask-wearing is not effective in the fight against the SARSCoV-2 pandemic, over $92 \%$ were persons from faculties other than medicine:

year of study $=1-3 \&$ is mask-wearing an efficient tool in the fight against the COVID-19 pandemic? $=$ no $\Rightarrow$ faculty $=$ other than medicine (support $23.08 \%$, trust $92.05 \%$ ) 
- Similarly, among the persons who answered that they did not get vaccinated with a non-compulsory vaccine other than those against influenza or COVID-19 and claimed that the COVID-19 vaccine is not safe, $92 \%$ were students of faculties other than medicine:

did you get vaccinated with another non-compulsory vaccine $?=$ no $\&$ are COVID-19 vaccines safe? $=$ no $\Rightarrow$ faculty $=$ other than medicine (support $13.11 \%$, trust $92 \%$ )

\section{Conclusions}

The obtained results confirm that students of the faculty of medicine have the highest level of knowledge about vaccination, with special focus on the COVID-19 vaccines. The vast majority believes in the effectiveness of vaccination and the methods of fight with the COVID-10 pandemic in use, e.g. hand washing and disinfection or wearing masks. They are also aware that the set rules of fight with the pandemic should be executed; they even tend to think that the rules should be strengthened. All of the above results in a large percentage of them having been vaccinated against the SARSCoV-2 virus with all the required doses. Students of other medical faculties have much less uniform opinions in this area, similarly to students of nonmedical faculties. Anti-vax theories of various kinds that concern the nonexistence of the SARS-CoV-2 virus, the ineffectiveness of vaccination, the ineffectiveness of the used methods of fight with the COVID-19 pandemic, or a sceptical attitude towards vaccines of any kind, are overwhelmingly associated with faculties other than medicine.

The used data-mining methods (correspondence analysis and basket analysis) allow to find interesting relations, difficult to find with the use of traditional methods of biostatistical analysis; they also make it possible to present the obtained results in a more interesting and visual manner.

\section{R E F E R E N C E S}

Artenstein, A.W. (2009). Vaccines: A Biography (1 ed.). New York City: Springer Science \& Business Media.

Askell-Williams, H., \& Lawson, M. (2004). A correspondence analysis of childcare students' and medical students' knowledge about teaching and learning. International Education Journal, 5(2), 176-204. 
Cohn, D. V. (2006). Pasteur. University of Louisville. Retrieved from: http:// pyramid.spd.louisville.edu/ eri/fos/interest1.html.

Hristovski, D., Stare, J., Peterlin, B., \& Dzeroski, S. (2001). Supporting discovery in medicine by association rule mining in Medline and UMLS. Medinfo, 10, 1344-1348.

Marchewka, A. K., Majewska, A., \& Młynarczyk, G. (2015). Działalność ruchu antyszczepionkowego, rola środków masowego komunikowania oraz wpływ poglądów religijnych na postawę wobec szczepień ochronnych. Post. Mikrobiol., 54(2), 95-102.

Milewska, A. J., Górska, U., Jankowska, D., Milewski, R., \& Wołczyński, S. (2011). The use of the basket analysis in a research of the process of hospitalization in the gynecological ward. Studies in Logic, Grammar and Rhetoric, 25(38), $83-98$.

Milewska, A. J., Jankowska, D., Górska, U., Milewski, R., \& Wołczyński, S. (2012). Graphical representation of the relationships between qualitative variables concerning the process of hospitalization in the gynecological ward using correspondence analysis. Studies in Logic, Grammar and Rhetoric, 29(42), $7-25$.

Needham, J. (2004). Science and civilisation in China. T. VI, Część 6: Biology and Biological Technology: Medicine. Cambridge: Cambridge University Press.

Owczarek, D. (2021). Ekspert o teoriach spiskowych: Nie da się dyskutować z faktami naukowymi. Retrieved from: https://www.dw.com/pl/ekspert-o-teoriachspiskowych-nie-da-si\%C4\%99-dyskutowa\%C4\%87-z-faktami-naukowymi/a56306576

Stanimir, A. (2008). Wykorzystanie analizy korespondencji w badaniach marketingowych. In Zastosowanie metod statystycznych w badaniach marketingowych III (pp. 337-346). Kraków: StatSoft Polska.

Tadeusiewicz R. (2006). Data Mining jako szansa na relatywnie tanie dokonywania odkryć naukowych poprzez przekopywanie pozornie całkowicie wyeksploatowanych danych empirycznych. In: J. Wątroba (Ed.), Statystyka i Data Mining w badaniach naukowych, Kraków: StatSoft Polska.

Williams, G. (2010). Angel Of Death; the story of smallpox. Basingstoke, UK: Palgrave Macmillan.

Wood, M.E. (2016). Biting Back. Chemical Heritage Magazine, 28(2), 7. 